\title{
Invertebrate predation in Lake Michigan: Regulation of Bosmina longirostris by Leptodora kindtii
}

\author{
Donn K. Branstrator and John T. Lehman
}

Department of Biology, Natural Science Building, University of Michigan, Ann Arbor 48109

\begin{abstract}
The density of Bosmina longirostris (O. F. Mucller) declined 100-fold between 25 June and 20 August 1985 in Lake Michigan; a similar pattern of changing abundances was observed in 1986 but not in 1987 or 1988. Bosmina collected from periods before and during the decline in 1985 and 1986 were examined for size at maturity and clutch size. Population size-frequency distributions suggest that some animals began to mature at smaller sizes during the decline in 1985 . In some cases, the average clutch size for Bosmina of similar body lengths was significantly reduced during the decline in 1985 and 1986. These data suggest that food limitation was a factor in the species decline in both years. Gut content analyses indicate that of seven potential predators, Leptodora kindtii (Focke) was probably most responsible for Bosmina mortality. There is ample evidence that Leptodora does not consume strictly fluid from its prey: juvenile Leptodora ate mainly smaller prey that included Bosmina and the rotifer Conochilus; adults ate a broader size range of prey that included mainly Bosmina, Daphnia, and copepods. In 1987 and 1988, Bythotrephes cederstroemii Schoedler was abundant in Lake Michigan and was contemporaneous with collapse of the Leptodora population and concurrent increase of the Bosmina population in August and September. Predation by the large copepods Epischura lacustris S. A. Forbes and Limnocalanus macrurus Sars did not appear to have any significant effect on the population dynamics of Bosmina.
\end{abstract}

Lake Michigan has long been regarded as an ecosystem in which visual planktivory by fish exerts a dominant structuring influence. The exposition by Wells (1970) documenting changes in zooplankton populations in response to predation by alewife, Alosa pseudoharengus (Wilson), helped to establish size-selective predation as one of the paradigms of plankton community ecology. Wells observed that the successful invasion of alewife into Lake Michigan was associated with depressed densities of Daphnia, Leptodora, Limnocalanus, Epischura, and other large-bodied crustacean taxa and with increased densities of smaller taxa, particularly Bosmina longirostris.

Although Wells (1970) argued convincingly that the large plankton were removed by selective planktivory, no rationale was advanced for the numerical increase in Bosmina. In retrospect, the taxon's success may have stemmed from relaxed competition for

\footnotetext{
Acknowledgments

We thank James Bowers, Douglass Burdette, Robert Gensemer, Robert Dorazio, Glenn Warren, and the captain and crew of the RV Laurentian for assistance with field sampling. Robert Black and Patricia ChowFraser provided suggestions for the manuscript.

This research was supported by NSF grants OCE 8415970, OCE 86-13880, and OCE 87-16187.
}

food resources or from reduced planktivory by invertebrates. That planktivory played a role in Bosmina's dynamics seems plausible but because several putative predators declined simultaneously the relative importance of each is indecipherable from his data.

Recent changes of Lake Michigan's 7ooplankton community, wrought by a new invading species, provide an opportunity to further understand factors controlling Bosmina dynamics there. In summers 1985 and 1986, Bosmina populations in offshore Lake Michigan experienced similar abundance cycles. Populations quickly reached peak densities in late June of $31,000 \mathrm{~m}^{-2}$ (1985) and early July of $70,000 \mathrm{~m}^{-2}$ (1986), and then decreased steadily to densities of 600 $\mathrm{m}^{-2}(1985)$ and $9,000 \mathrm{~m}^{-2}(1986)$ by midAugust. In 1987, however, major changes occurred in the composition of the offshore zooplankton community; they were attributed in part to predation by the invading cladoceran, Bythotrephes cederstroemii (Lehman 1988). That summer, and in 1988, Bosmina did not decline in August and September as it had in 1985 and 1986 during those months. In this report we use the population changes associated with this event to investigate the controls on Bosmina in Lake Michigan. 


\section{General approach}

Factors responsible for the seasonal declines of Bosmina in Lake Michigan in 1985 and 1986 were hypothesized to be resource limitation, predation, or a combination of the two. Because populations in 1985 and 1986 declined at summer epilimnetic water temperatures that permitted continued growth in 1987 and 1988, ambient temperature was not considered to be a cause. Bosmina size-frequency distributions and sizespecific egg ratios (average clutch size per body-length class) were examined for changes that would suggest food limitation as a factor. Gut analyses were performed on the potential predators to determine if any were eating Bosmina. On the basis of physical presence and potential for carnivory, these predators were young-of-the-year (YOY) Coregonus hoyi (Gill), and the crustacean zooplankton Mysis relicta (Lovén), Leptodora kindtii, Epischura lacustris, Limnocalanus macrurus, Senecella calanoides Juday, and cyclopoids [mainly Diacyclops bicuspidatus thomasi (S. A. Forbes)]. Planktivory on Bosmina by YOY $C$. hoyi was immediately rejected based on results of gut analyses from 1985 (Warren and Lehman 1988), which showed that these vertebrates consumed cyclopoid copepodids and Daphnia pulicaria Forbes almost exclusively during the time when Bosmina declined. Evidence for the potential carnivory of $M$. relicta (Bowers and Vanderploeg 1982), $L$. kindtii (Mordukhai-Boltovskaia 1958), $E$. lacustris (Chow-Fraser and Wong 1986), $L$. macrurus, and $S$. calanoides (Nero and Sprules 1986) and cyclopoids (Fryer 1957) made these species candidates for study.

\section{Methods}

Zooplankton collections-Zooplankton were collected during summer 1985-1988 in Lake Michigan at a reference station $\left(43^{\circ} \mathrm{N}, 86^{\circ} 40^{\prime} \mathrm{W}\right), 36 \mathrm{~km}$ offshore from Grand Haven, Michigan (Lehman et al. 1990). In 1985 and 1986, large crustacean zooplankton were collected by Tucker trawl with a mouth opening of $1 \mathrm{~m}^{2}$ and a net aperture of $300 \mu \mathrm{m}$ and by $1-\mathrm{m}$-diameter Puget Sound vertical closing nets with 130or 300- $\mu \mathrm{m}$ mesh. Trawl and nets were towed at $0.5-1 \mathrm{~m} \mathrm{~s}^{-1}$. Large- and small-bodied zooplankton were collected by submersible pump discharged through either 63- or 130$\mu \mathrm{m}$ mesh (Dorazio et al. 1987; Lehman et al. 1990). Pump collections were integrated over 10-m intervals. Temperatures were measured by mechanical bathythermograph (1985 and 1986) and by electronic bathythermograph (1987 and 1988). In 1987 and 1988 , zooplankton were collected exclusively by closing nets fitted with $130-\mu \mathrm{m}$ mesh. Zooplankton were immediately narcotized with carbonated water and preserved in a sugar-Formalin solution (Haney and Hall 1973). Samples collected by the trawl and closing nets were split by volume with a Folsom plankton splitter. Representative fractioned samples were counted to determine population densities of species by date and depth. Pump samples were subsampled by pipette and counted.

Bosmina-The potential effects of resource limitation on Bosmina were determined by examining the animals for changes in size at maturity and clutch size. Goulden et al. (1982) reported that Bosmina grown under low-food conditions matures at a smaller size than better fed individuals. The smallest sizes at which Lake Michigan Bosmina reached second and third (primaparous) instars were determined from population size-frequency distributions. Instars were identified from modes of the distributions and numbers of barren vs. fecund females in individual frequency cells. We hypothesized that declining resources would have caused Bosmina to mature at a smaller size.

Somatic growth in Bosmina continues after primaparity; thus later adult instars have larger brood chambers and can carry more eggs. Kerfoot (1974) found that Bosmina grown under low-food conditions carries fewer eggs per clutch than well-fed individuals; this relationship held over a range of carapace lengths. We hypothesized that de-clining resources would have forced Bosmina to decrease clutch size.

To test both hypotheses, we measured Bosmina for body length and clutch size. Plankton samples were filtered on $50-\mu \mathrm{m}$ mesh and rinsed with filtered tapwater (50 $\mu \mathrm{m})$ to remove excess Formalin. After re- 
suspension, random subsamples of $5 \mathrm{ml}$ were extracted with a widebore Finn injection pipette and discharged into a zooplankton counting chamber. Animals were viewed on a Wild M5A stereo dissecting microscope at $25 \times$ magnification. As encountered, individuals were removed to and mounted on glass microscope slides in 50\% glycerin. Coverslips were sealed with Permount histological mounting medium (Fisher SO-P15). Individuals were measured for total body length (Kerfoot 1980) with the aid of an ocular micrometer under $190 \times$ magnification on an Olympus BHA compound stereo microscope. Clutch size was recorded.

Bosmina egg volume was also estimated to determine whether egg size could explain differences in clutch size across dates. For individuals carrying eggs in an early stage of embryonic growth, dimensions of one egg per clutch were measured. The yolk of these eggs was transparent and nongranular, the oil droplet was visible, and the membrane had not been cast off. Egg volume $(V)$ was approximated as

$$
V=4 / 3 \pi A B^{2}
$$

where $A$ and $B$ are the longest and shortest radii.

Death rates for Bosmina were calculated in order to determine predation rates necessary to account for the decline (Paloheimo 1974). The instantaneous birth rate $(b)$ was taken as

$$
b=\ln (1+E) / D
$$

where $E$ is the egg ratio (average number of eggs per female) and $D$ the egg development time. Because the animals were distributed throughout the water column, they experienced different temperatures, thus different egg development times. To compute an average population egg development time for each date, we determined the population density of Bosmina in each stratum from pump samples. Between two and six series of samples were taken over $24 \mathrm{~h}$ to determine the diurnal vertical distribution of Bosmina.

The corresponding fraction of eggs in each stratum was estimated by multiplying a total population egg ratio $(E)$ times Bosmina density in that stratum for each period. $\chi^{2}$ homogeneity tests showed that $E$ was not significantly different by stratum on any date $(P>0.05)$. Values for the dependency of egg development rate on temperature were taken from Vijverberg (1980). The population egg development time was then computed as an average, weighted to account for the time that different percentages of eggs experienced different temperatures over $24 \mathrm{~h}$. The instantaneous population growth rate $(r)$ was taken as

$$
r=\left(\ln N_{t}-\ln N_{0}\right) / t
$$

where $N_{t}$ and $N_{0}$ are the population densities at time $t$ and 0 , and $t$ is the time between sample dates. The instantaneous death rate (d) was taken as

$$
d=b-r \text {. }
$$

Daily death rate (DR) was then taken as

$$
\mathrm{DR}=d\left(N_{0}+N_{t}\right) / 2 \text {. }
$$

Copepods and Leptodora-Animals were examined for prey remains in their digestive tracts. Results were used chiefly to identify predators of Bosmina. Subsamples of $5 \mathrm{ml}$ were prepared as for Bosmina and then discharged into a glass Petri dish. Species were identified under bright-field microscopy on the Wild microscope at $25 \times$ magnification. Zooplankton were removed as encountered and placed individually on glass slides. Leptodora was measured from the center of the eye to the basc of the bifurcation in the tail spine. Each animal was completely covered with Hoyer's mounting medium $(200 \mathrm{~g}$ of chloral hydrate crystals, $20 \mathrm{ml}$ of glycerin, $30 \mathrm{~g}$ of photopurified gum arabic, and 50 $\mathrm{ml}$ of water), then covered with a coverslip and sealed with Permount. Hoyer's medium dissolves organic tissue and allows observation of the contents in the digestive tract without dissection.

The contents of each gut were identified by differential interference contrast microscopy on the Olympus microscope at $190 \times$ and $750 \times$ magnifications. This technique made it possible to distinguish slight structural details in the remains of ingested food. As we became skilled at assigning prey remains to specific taxa, animals were re-examined to ensure that remains in earlier 
specimens had not been overlooked. Each animal was examined at $\sim 2$ weeks and 3 , 6 , and 12 months after preparation. Rotifers in gut contents were identified by trophi and loricas.

We identified Bosmina by postabdominal claw morphology. Postabdominal claw length was recorded for those claws lying in favorable orientations. A regression equation relating the body length of Bosmina to claw length was used to estimate the body lengths of ingested Bosmina (Eq. 6).

$$
\begin{aligned}
\mathrm{TL} & =15.38 \mathrm{CL}-0.12 \\
(n & \left.=207, r^{2}=0.888\right)
\end{aligned}
$$

where TL is total body length ( $\mathrm{mm})$ and $\mathrm{CL}$ is claw length $(\mathrm{mm})$. We also identified Bosmina by the diagnostic second antennae. Although Eubosmina coregoni (Baird) possesses morphologically similar antennae, this species was not detected in 1985 and was rare in 1986 ( 18 individuals $\mathrm{m}^{-2}$ on 8 July 1986).

We identified Daphnia by postabdominal claw morphology and thoracic comb appendages. Claw length was recorded for claws lying in favorable orientations. A regression equation from Warren and Lehman (1988) was used to estimate the total length (center of eyespot to base of tail spine) of ingested Daphnia.

Copepods were identified by caudal rami, mandibles, and setous appendages including first antennae and thoracic legs.

Some prey appendages were assignable only to the following two general categories: Cladocera (Daphnia and Bosmina) and Cladocera-copepod. Cladocera were distinguished by mandibles. Cladocera-copepod possessed setous appendages but could not be discriminated further.

It was possible to count and verify the number of animals ingested only when specific parts such as trophi, postabdominal claws, or mandibles were present. These structures usually do not break apart during ingestion and gut passage, and because each animal possesses a small number of these parts, it was easy to verify number of prey.

Mysis-For each specimen, the crop was excised and placed on a glass slide. Contents were teased apart, covered with Hoyer's medium and a coverslip, and then sealed with Permount. Prey identification was the same as for copepods and Leptodora. We also identified Bosmina by rostra and antennules. The one Leptodora found was identified by a mandible.

\section{Results}

Sampling precision - The mean C.V. for crustacean zooplankton in No. of animals $\mathrm{m}^{-2}$ equals $19 \%$ for pump collections (Dorazio et al. 1987) and $18.5 \%$ for vertical net collections (Lehman et al. 1990). Because two or more replicates were always taken, the standard error (SE) for the mean areal estimates in Fig. 1 is usually $<15 \%$ of the reported value.

Bosmina-On most dates, population size-frequency distributions have multiple modes that represent first, second, and adult instars (Fig. 2). In 1985, some animals matured at smaller sizes in July than in June, and some matured at smaller sizes in August than in July. Some second-instar individuals also appeared at reduced size later in summer 1985 . No consistent seasonal pattern was evident in 1986.

The effect of date on average clutch size was significant in half of the body-length classes in 1985 (Table 1). For these classes, average clutch size was larger in June than in July and August. Among July and August dates only, the effect of date on clutch size was not significant in any body-length class (Kruskal-Wallis $P>0.05, \mathrm{df}=2$ ). In 1986, we collected no Bosmina in June samples, and the effect of date on clutch size was not significant in any body-length class (Kruskal-Wallis $P>0.05, \mathrm{df}=2$ ). Egg volume did not change significantly during either year (Table 2, one-way ANOVA 1985, $P=$ $0.518 ; 1986, P=0.065$ ).

In 1985 , the frequency of fecund to barren females was significantly different among dates (Table $3, \chi^{2}$ homogeneity, $P=0.027$ ). The proportion of fecund females appears to have been larger in June than during the rest of the season; the frequency of fecund to barren females was not significantly different among July and August dates alone ( $\chi^{2}$ homogeneity, $P=0.494$ ). In 1986 , the frequency of fecund to barren females was not significantly different among dates $\left(x^{2}\right.$ homogeneity, $P=0.489$ ). 


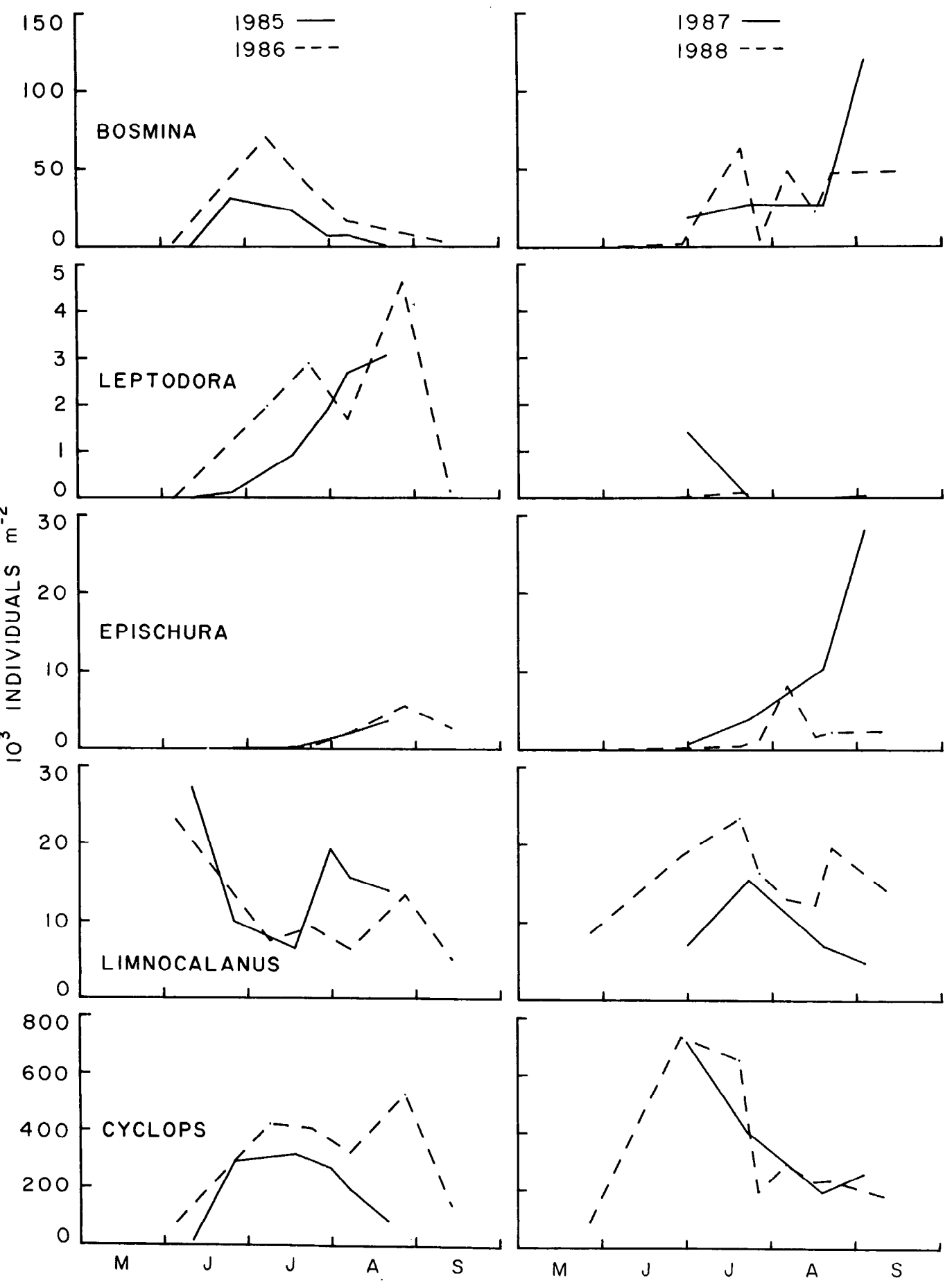

Fig. 1. Densities of Bosmina longirostris and potential prcdators at the offshore reference station from May to September 1985-1988. Copepod densities are stages C1-C6. 

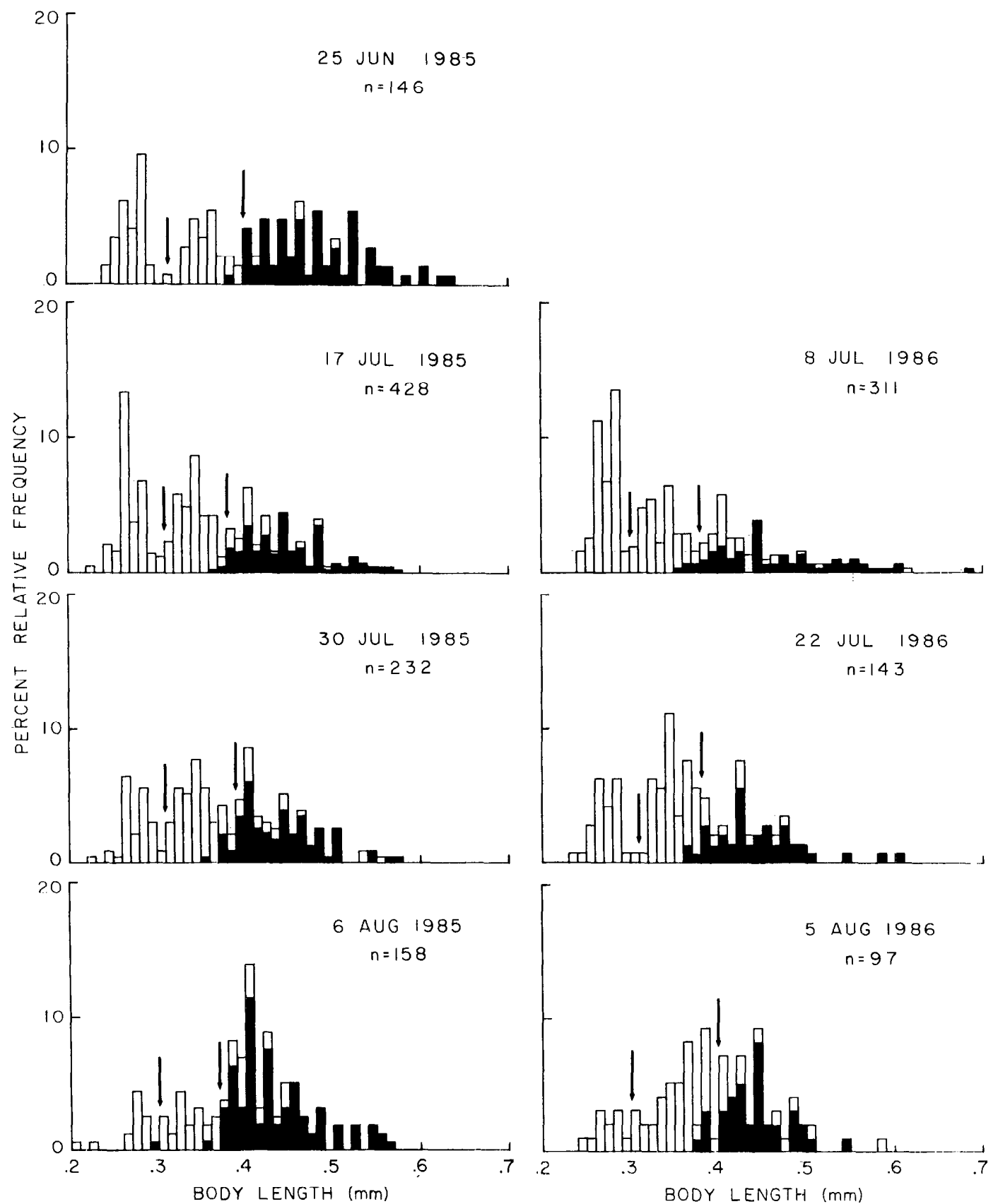

Fig. 2. Population size-frequency distributions for Bosmina longirostris at the offshore reference station for four 1985 and three 1986 dates. Black bars indicate fecund individuals. Arrows indicate estimates of the smallest second- and third-instar individuals on each date.

Daily death rates (DR) for Bosmina were calculated for two 1985 time periods: DR for 25 June-17 July $=2,780$ Bosmina $\mathrm{m}^{-2}$ $\mathrm{d}^{-1}$; DR for 17-30 July $=2,215$ Bosmina $\mathrm{m}^{-2} \mathrm{~d}^{-1}$.
Predator densities -During 1985 and 1986 when Bosmina was declining, Leptodora and Epischura were increasing in densities (Fig. 1). Densities of other predators during that time did not demonstrate con- 
Table 1. Average clutch size $\pm \mathrm{SE}(n)$ per body-length class for fecund Bosmina longirostris during 1985 and 1986 at the offshore reference station.

\begin{tabular}{ccccc}
\hline $\begin{array}{c}\text { Body length } \\
(\mathrm{mm})\end{array}$ & 25-26 Jun 85* & 17 Jul 85 & 30 Jul 85 & 6 Aug 85 \\
\hline $0.40-<0.42 \dagger$ & $1.48 \pm 0.11(23)$ & $1.05 \pm 0.05(22)$ & $1.15 \pm 0.08(20)$ & $1.05 \pm 0.05(21)$ \\
$0.42-<0.44 \dagger$ & $1.79 \pm 0.09(28)$ & $1.50 \pm 0.17(18)$ & $1.44 \pm 0.18(9)$ & $1.13 \pm 0.09(15)$ \\
$0.44-<0.46$ & $1.97 \pm 0.12(31)$ & $1.81 \pm 0.10(26)$ & $2.00 \pm 0.15(14)$ & $1.92 \pm 0.14(13)$ \\
$0.46-<0.48$ & $2.79 \pm 0.19(14)$ & $1.90 \pm 0.10(10)$ & $2.27 \pm 0.20(11)$ & $2.33 \pm 0.42(6)$ \\
$0.48-<0.50$ & $3.24 \pm 0.24(21)$ & $2.38 \pm 0.20(16)$ & $2.57 \pm 0.30(7)$ & $2.40 \pm 0.25(5)$ \\
$0.50-<0.52 \dagger$ & $3.88 \pm 0.26(16)$ & $2.80 \pm 0.20(5)$ & $3.17 \pm 0.31(6)$ & $2.67 \pm 0.33(3)$ \\
& & & & \\
& & 22 Jul 86 & 5 Aug 86 & \\
$0.40-<0.42$ & $1.22 \pm 0.15(9)$ & $1.00 \pm 0.00(5)$ & $1.00 \pm 0.00(7)$ & \\
$0.42-<0.44$ & $1.60 \pm 0.24(5)$ & $1.30 \pm 0.15(10)$ & $1.00 \pm 0.00(7)$ & \\
$0.44-<0.46$ & $1.71 \pm 0.13(14)$ & $2.00 \pm 0.00(7)$ & $2.10 \pm 0.10(10)$ & \\
$0.46-<0.48$ & $2.50 \pm 0.22(6)$ & $2.33 \pm 0.33(6)$ & $2.00 \pm 0.00(2)$ & \\
$0.48-<0.50$ & $3.00 \pm 0.37(6)$ & $2.75 \pm 0.48(4)$ & $2.40 \pm 0.40(5)$ & \\
\hline
\end{tabular}

* Some individuals were selccted nonrandomly from samples.

$\dagger$ Mean clutch sizes are significantly different across all dates (Kruskal-Wallis $P<0.05$, of $\approx 3$ ).

tinued increase. Bythotrephes was then first detected in Lake Michigan on 25 August 1986 (Lehman 1987). In 1987 and 1988, Bosmina did not decline through August and September as it had in the previous $2 \mathrm{yr}$. Leptodora was present briefly in 1987 and 1988 in June and mid-July but then became virtually undetectable. Copepod densities were comparable to 1985 and 1986 values on most dates. Areal Mysis densities remained constant for the period 1985-1989 (mean $\approx 110$ individuals $\mathrm{m}^{-2}$ ) (Lehman et al. 1990). Senecella was always $<1,000$ individuals $\mathrm{m}^{-2}$ during the months relevant here for 1985-1988.

Predator gut analyses-Animals cleared progressively in Hoyer's medium over periods of several weeks. After 3 months, most food items were visible. We occasionally found and identified additional prey after 3

Table 2. Average volume $\left(\mu \mathrm{m}^{3} \times 10^{5}\right) \pm \mathrm{SE}(n)$ for Bosmina longirostris eggs at the offshore reference station.

\begin{tabular}{cl}
\hline & Egg volume \\
\hline 1985 & $6.13 \pm 0.14(46)$ \\
$25-26 \mathrm{Jun}$ & $5.88 \pm 0.12(31)$ \\
$17 \mathrm{Jul}$ & $6.19 \pm 0.30(12)$ \\
$30 \mathrm{Jul}$ & $5.82 \pm 0.35(12)$ \\
6 Aug & \\
1986 & $6.62 \pm 0.21(23)$ \\
$8 \mathrm{Jul}$ & $5.79 \pm 0.24(11)$ \\
$22 \mathrm{Jul}$ & $6.26 \pm 0.32(9)$ \\
5 Aug & \\
\hline
\end{tabular}

months, but such data were the results of our increasing familiarity with the prey remains and not related to the clearing agent. In copepods, food was usually found packaged in small boluses throughout the entire length of the gut. In Leptodora, almost all prey remains were found in the stomach portion of the gut. In Mysis, examination was confined to the crop. Occasional analyses of the intestine revealed diatom frustules only.

Senecella showed no evidence of predation on Bosmina and only minimal selection for animal food compared to the other predators (Table 4). Limnocalanus consumed a range of prey including one Bosmina. Cyclopoids were eating Bosmina, but, as with Limnocalanus, direct evidence is limited to one specimen. Epischura con-

Table 3. Number of fecund and barren female Bosmina longirostris ( $\geq 0.40-\mathrm{mm}$ body length) at the offshore reference station. All animals were selected randomly from samples.

\begin{tabular}{crc}
\hline & Fecund & Barren \\
\hline 1985 & 71 & 4 \\
25 June & 112 & 26 \\
17 Jul & 71 & 19 \\
30 Jul & 72 & 12 \\
6 Aug & & \\
1986 & 26 & 8 \\
8 Jul & 36 & 7 \\
22 Jul & 33 & 12 \\
5 Aug & & \\
\hline
\end{tabular}


Table 4. Number of copepods examined and total prey found in specimens from the offshore reference station, 1985. Number of animals selected from certain dates reported as taxon: number (date). Senecella: 24 (18 July); Limnocalanus: 45 (25-26 June), 66 (17-18 July), 29 (30 July), 21 (6 August); cyclopoids: 32 (25 June), 41 (17-18 July), 11 (30 July), 13 (6 August); Epischura: 20 (17 July), 26 (30 July), 14 (6 August).

\begin{tabular}{|c|c|c|c|c|c|c|c|}
\hline \multirow[b]{2}{*}{ Predator } & \multirow{2}{*}{$\begin{array}{l}\text { No. } \\
\text { examined }\end{array}$} & \multicolumn{6}{|c|}{ Prey type } \\
\hline & & Daphnia & Bosmina & Copepod & Clad/cope & Rotifer* & Peridinium \\
\hline Senecella & 24 & 0 & 0 & 0 & 0 & 3 & 0 \\
\hline Limnocalanus & 161 & 0 & 1 & 3 & 5 & 3 & 1 \\
\hline Cyclopoids $†$ & 97 & 1 & 1 & 0 & 3 & 2 & 0 \\
\hline Epischura & 60 & 1 & 0 & 3 & 0 & 21 & 78 \\
\hline
\end{tabular}

* Includes Keratella cochlearis (Gosse), Kellicottia longispina (Kellicott), Conochilus, and unidentifiable taxa.

$\uparrow$ Includes Diacyclops bicuspidatus thomasi and Acanthocyclops vernalis (Fischer).

sumed a variety of food items and, based on frequency of presence in the guts, Peridinium and rotifers, mainly Keratella cochlearis, were most common. Algal taxa other than Peridinium are excluded from Table 4. Limnocalanus and Senecella guts were usually filled with diatoms, mainly Melosira and Tabellaria. Cyclopoid and Epischura guts occasionally contained algae.

Leptodora ate Cladocera, copepods, and rotifers (Table 5). Two pairs of incudate trophi, probably assignable to Asplanchna, and one pair of malleate trophi are not included in Table 5. Conochilus trophi were not assignable to species, but Conochilus unicornis Rousselet was the only member of that genus found in sample collections from Lake Michigan during the years relevant here. For all dates, most of the Leptodora guts examined contained observable prey remains (Table 5).

Daphnia and copepod remains were found more frequently in larger Leptodora while Conochilus was found exclusively in Leptodora $<8 \mathrm{~mm}$ long (Fig. 3). The rotifers excluded from Table 5 were found in Lep- todora $<6 \mathrm{~mm}$ long. We found Bosmina more consistently than other prey among a wider range of Leptodora sizes. Larger Leptodora consumed larger Cladocera (Fig. 4). We found few Daphnia $>1.0 \mathrm{~mm}$ in Leptodora.

Given 1985 densities for Leptodora and Bosmina DRs, we estimated that predation rates of 6 Bosmina (Leptodora) $)^{-1} \mathrm{~d}^{-1}$ for the period 25 June-17 July and 2 Bosmina (Leptodora) $)^{-1} \mathrm{~d}^{-1}$ for 17-30 July would account for $100 \%$ of Bosmina mortality between dates.

Mysis consumed a variety of prey taxa including Bosmina (Table 6). Given 1985 Mysis densities (Lehman et al. 1990) and Bosmina DRs, we calculated that each $M y$ sis on average would have to consume 19 Bosmina $\mathrm{d}^{-1}$ for the period 25 June-17 July and 18 Bosmina $\mathrm{d}^{-1}$ for the period $17-30$ July to account for $100 \%$ of Bosmina mortality between dates.

\section{Discussion}

Bosmina in Lake Michigan - The decline in density of Bosmina in offshore Lake Michigan in 1985 and 1986 appears to be

Table 5. Number of Leptodora kindtii examined (number with observable prey remains) and total identifiable prey found in specimens from the offshore reference station.

\begin{tabular}{ccccccccc}
\hline & \multicolumn{8}{c}{ Prey type } \\
\cline { 5 - 8 } & No. examined & Daphnia* & Bosmina & Cladocera & Copepod & Clad/cope & Conochilus \\
\hline 1985 & & & & & & & \\
16-18 Jul & $193(137)$ & 33 & 42 & 2 & 19 & 33 & 69 \\
30 Jul & $80(60)$ & 25 & 5 & 0 & 8 & 8 & 18 \\
6-7 Aug & $54(48)$ & 21 & 1 & 0 & 5 & 7 & 1 \\
20 Aug & $35(23)$ & 9 & 0 & 0 & 1 & 6 & 0 \\
1986 & & & & & & & & 103 \\
8 Jul & $106(69)$ & 30 & 7 & 0 & 10 & 5 & \\
\hline
\end{tabular}

* Includes D. galeata mendotae Birge, D. pulicaria, and D. retrocurva Forbes. 


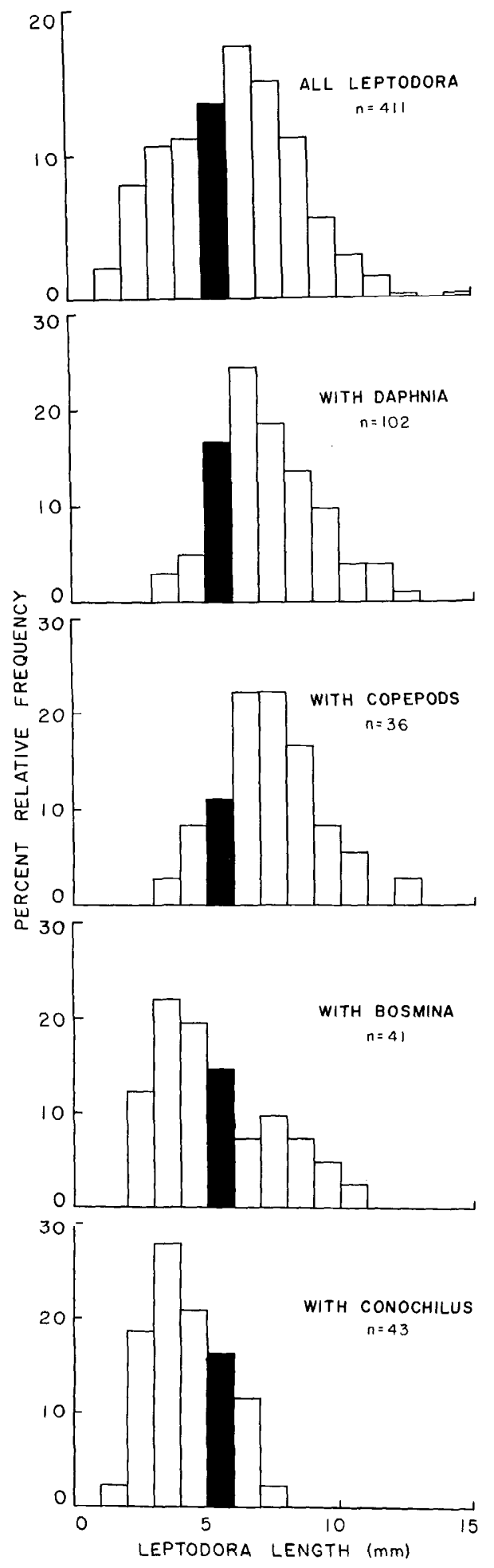

the result of food limitation and predatory mortality, the latter imposed mainly by Leptodora.

In 1985, Bosmina matured at a larger body length in June than during July and August (Fig. 2). In addition, Bosmina in June carried, on average, significantly more eggs per clutch than animals in July or August for 3 of 6 body-length classes (Table 1). During July and August, average clutch size did not differ significantly. The ratio of fecund to barren females $\geq 0.40 \mathrm{~mm}$ long was also significantly larger in June than in July or August, but this ratio was not different among July and August dates (Table 3). These data suggest that Bosmina experienced food limitation between June and the first July date. During July and August, Bosmina showed no further signs of food limitation, except for the presence of some smaller mature individuals in the population.

In 1986 , there was no pattern in size at maturity to indicate that Bosmina was food limited (Fig. 2). In addition, average clutch size did not decrease significantly for any body-length class, but a trend of decreasing clutch size was evident among most bodylength classes (Table 1). This trend suggests that food limitation may have been a factor in the 1986 decline of Bosmina. The ratio of fecund to barren females was not significantly different among dates, however (Table 3). For neither 1985 nor 1986 did average egg volume change significantly (Table 2). Clutch size alone was probably an adequate representation of reproductive investment on each date.

There is other indirect evidence that resource conditions declined for Bosmina both years. Chl $a$ concentration, a measure of algal biomass, decreased from the surface to $20 \mathrm{~m}$ at the reference station from June through July in 1985 and 1986 (Lehman

Fig. 3. Size-frequency distribution for all Leptodora kindtii examined from the offshore reference station, 1985 and 1986, and distributions for those animals whose guts contained various prey items. The 5$6-\mathrm{mm}$ cell is blackened throughout. 


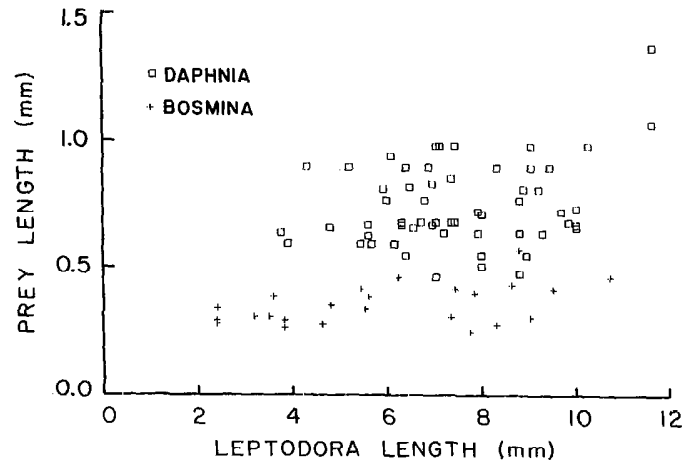

Fig. 4. Cladoceran prey eaten by Leptodora kindtii from the offshore reference station, 1985 and 1986. Daphnia includes $D$. galeata mendotae, D. pulicaria, and $D$. retrocurva.

1988). This decline is consistent with our evidence for food limitation.

Gut content analyses revealed that two copepod taxa, Limnocalanus and cyclopoids, were eating Bosmina in 1985 (Table 4). Reports suggest, however, that these copepods are not effective predators on Bosmina. Nero and Sprules (1986) found very low clearance rates for Limnocalanus on Bosmina and attributed them in part to Bosmina's defensive mucro. Kerfoot (1977) showed under laboratory conditions that the attack success rate of cyclopoids on Bosmina is low. Direct evidence for predation by Epischura on Bosmina was not detected in our samples, even though it is a predator on Bosmina.

Leptodora guts contained substantial evidence for predation on Bosmina (Table 5). Calculated predation rates of 2-6 Bosmina (Leptodora) $)^{-1} \mathrm{~d}^{-1}$ were necessary to account for $100 \%$ of Bosmina mortality from 25 June--30 July 1985. Mordukhai-Boltovskaia (1958) reported that a Leptodora 3 mm long can eat 11-12 Polyphemus pedic- ulus Linnaeus $\mathrm{d}^{-1}$ and that individuals 5-6 $\mathrm{mm}$ long can eat $30 \mathrm{~d}^{-1}$. Browman et al. (1989) reported that a Leptodora can eat 14 Daphnia pulex Leydig $\mathrm{d}^{-1}$. Leptodora could probably account for $100 \%$ of 1985 Bosmina mortality.

Mysis was also consuming Bosmina (Table 6). Calculated predation rates of 18-19 Bosmina (Mysis) $)^{-1} \mathrm{~d}^{-1}$ were necessary to account for $100 \%$ of observed mortality. Bowers and Vanderploeg (1982) reported in situ predation rates for Lake Michigan Mysis, held in enclosures, of about 30 Bosmina $(M y s i s)^{-1} \mathrm{~d}^{-1}$, which could account for all of the requisite Bosmina mortality observed here. The enclosure experiments, however, do not mimic temporal patterns of interaction between Mysis and Bosmina in situ. Bosmina is susceptible to predation by $M y$ sis for only a fraction of each day. Bosmina remains almost exclusively in the metalimnion and epilimnion, while Mysis ascends to the metalimnion only at night (Lehman et al. 1990). Beeton and Bowers (1982) reported data from sample collections and echo location that suggest Lake Michigan Mysis spends only 7-8 $\mathrm{h} \mathrm{d}^{-1}$ in the metalimnion and epilimnion during the summer months relevant here. Mysis predation rates would have to be about $2 \times$ rates reported by Bowers and Vanderploeg (1982) to account for $100 \%$ of observed Bosmina mortality. Mysis, moreover, was as abundant in 1987 and 1988 as in 1985 and 1986 (Lehman et al. 1990).

In 1986, Bosmina demographic trends were similar to 1985 patterns (Fig. 1). All predators examined for gut contents from 1985 were present in comparable densities in 1986. In addition, gut analyses revealed that Leptodora collected on 8 July 1986 was eating Bosmina (Table 5). These data sug-

Table 6. Number of Mysis relicta examined and total prey found in specimens from the offshore reference station.

\begin{tabular}{|c|c|c|c|c|c|c|c|c|}
\hline \multirow[b]{2}{*}{1985} & \multicolumn{8}{|c|}{ Prey type } \\
\hline & Mysis & Daphnia* & Bosmina & Cladocera & Leptodora & Copepod & Rotifert & Peridinium \\
\hline $26 \mathrm{Jun}$ & 10 & 9 & 10 & 0 & 0 & 12 & 8 & 0 \\
\hline $18 \mathrm{Jul}$ & 9 & 10 & 18 & 10 & 1 & 24 & 81 & 17 \\
\hline $31 \mathrm{Jul}$ & 9 & 14 & 5 & 4 & 0 & 49 & 15 & 7 \\
\hline
\end{tabular}

* Includes $D$. galeata mendotae, $D$. pulicaria, and D. retrocurva.

$\dagger$ Includes Kellicottia longispina, Keratella cochlearis, and unidentifiable taxa. 
gest that predation by Leptodora was also a major source of mortality for Bosmina in 1986.

Zooplankton population dynamics in 1987 and 1988 support the notion that Leptodora was responsible for much of the Bosmina mortality in 1985 and 1986. In 1987 and 1988, Leptodora was present in late June but was undetectable in July and August. Its decline was concurrent with the establishment of Bythotrephes in Lake Michigan (Lehman 1988). Leptodora failed to coexist with Bythotrephes when the latter reached high abundance. Berg and Garton (1988) also reported a negative correlation between seasonal Bythotrephes and Leptodora densities in western Lake Erie. The mechanism for displacement of Leptodora is still under study; the main reason may be direct mortality by Bythotrephes or competition for food, particularly for small Daphnia. Zooplankton predators other than Leptodora remained in 1987 and 1988; they reached densities at least as high as in 1985 and 1986 (Fig. 1). Bosmina densities, in the absence of Leptodora in 1987 and 1988, were higher in August and September than in 1985 and 1986. Although other predators were probably eating Bosmina in 1987 and 1988, their combined effect was apparently not great enough to prevent continued population growth in those years. By comparison, we suggest that additional mortality imposed by Leptodora in 1985 and 1986 was a key factor in the decline in Bosmina densities in both years.

Previous studies indicate that mortality imposed by Leptodora can reduce the densities of cladoceran populations. Field studies have illustrated the impact of Leptodora on populations of Daphnia galeata mendotae in Baseline Lake, Michigan (Hall 1964), Daphnia schoedleri Sars in Canyon Ferry Reservoir, Montana (Wright 1965), and Daphnia hyalina Leydig in Lago Maggiore, Italy (De Bernardi 1974). Prophet (1982) reported that decreased densities of Bosmina in Reading Lake, Kansas, were associated with increased densities of Leptodora. Our data complement these reports.

We conclude that predation on populations themselves constrained by seasonal food limitation was responsible for the de- clines in Bosmina densities in offshore Lake Michigan in 1985 and 1986. In 1985, it appears that food limitation was more severe from June to July. Predation, mainly by Leptodora, appears to be most responsible for Bosmina mortality during July and August. Mysis was probably also an important predator during that time. There is some evidence that Bosmina was also food limited in 1986 during the dates reported here. Changes in the zooplankton community in 1987 and 1988 suggest that Leptodora predation was perhaps the key factor in 1985 and 1986.

Wells (1970) attributed depressed densities of large crustacean zooplankton in Lake Michigan in 1966 to selective planktivory by alewife. Among the taxa that had declined was a suite of invertebrate predators including Leptodora, Epischura, and Limnocalanus. Associated with that event was an increase in Bosmina densities during the same year. Given the results of this report, we suggest, by analogy, that reduced predation by Leptodora was a pivotal factor in the success of Bosmina during that period as well.

Predatory behavior by Leptodora-Suggestions exist that Leptodora ingests primarily fluid from prey (Mordukhai-Boltovskaia 1958; Cummins et al. 1969). However, like Edmondson and Litt (1987), we found entire copepods in the guts of Leptodora. Furthermore, most Leptodora guts examined here contained hard parts from prey (Table 5). Gut analyses reported by Edmondson and Litt (1987) and results here confirm that Leptodora in the field feeds on Cladocera, copepods, and rotifers (Table 5).

By number, Conochilus represented an important item in Leptodora's diet (Table 5). Correlative data suggest that Leptodora may be a primary predator of Conochilus in Lake Michigan. In 1987 and 1988, Conochilus increased in abundance over 1985 and 1986 densities (Sandgren and Lehman 1990). This shift is also correlated with the invasion of Bythotrephes and the decline of Leptodora. Thus, the loss of a key predator, Leptodora, may have permitted increased densities of Conochilus. Edmondson and Litt (1987) suggested that Leptodora may control population dynamics of Conochilus spp. 
in Lake Washington, Seattle. Their conclusion is also based on gut analyses and correlations of annual predator-prey densities.

The size-frequency distributions of Leptodora containing Daphnia, copepods, Bosmina, and Conochilus suggest that juveniles and adults ate different prey (Fig. 3). Juveniles ( $<5 \mathrm{~mm}$ long: Andrews 1948) ate mainly smaller prey-Bosmina and Conochilus - while adults ate a broader size range of prey that included mainly Bosmina, copepods, and Daphnia. The size relationships of predators and prey also suggest that larger prey are consumed by larger Leptodora (Fig. 4). Because juvenile and adult Leptodora were collected from the same depth strata, it is doubtful that the life stages encountered fundamentally different prey assemblages. We suggest that this empirical shift in diet may be a function of the larger body size and length of adult feeding appendages. It is not apparent that larger individuals can swim faster (Browman et al. 1989).

Our data support previous observations that invertebrate predators are size selective in their prey choice (Dodson 1974) and that large species of Cladocera attain sizes that reduce or eliminate their risk of predation by invertebrate predators, but small Cladocera never outgrow a vulnerable size (Lynch 1980). Leptodora rarely ate Daphnia $>1.0 \mathrm{~mm}$ in total length (Fig. 4). Furthermore, Leptodora $<5 \mathrm{~mm}$ long rarely ate Daphnia (Fig. 3). In contrast, Leptodora ate large Bosmina, $>0.5 \mathrm{~mm}$ in body length (Fig. 4). Bosmina was also vulnerable to juvenile Leptodora-some $<3 \mathrm{~mm}$ long. In general, it appears that larger Leptodora can consume larger prey; Daphnia is less vulnerable to Leptodora after growing to $>1.0$ $\mathrm{mm}$; and smaller prey taxa, such as Bosmina, are vulnerable to Leptodora at all sizes.

\section{References}

Andrews, T. F. 1948. The parthenogenic reproductive cycle of the cladoceran, Leptodora kindtii. Trans. Am. Microsc. Soc. 67: 54-60.

BeEton, A. M., AND J. A. Bowers. 1982. Vertical migration of Mysis relicta Lovên. Hydrobiologia 93: 53-61.
Berg, D. J., AND D. W. Garton. 1988. Seasonal abundance of the exotic predatory cladoceran, $B y$ thotrephes cederstroemi, in western Lake Erie. J. Great Lakes Res. 14: 479-488.

BOWERS, J. A., AND H. A. VANDERPLOEG. 1982. In situ predatory behavior of Mysis relicta in Lake Michigan. Hydrobiologia 93: 121-131.

Browman, H. I., S. KRUSE, AND W. J. O'Brien. 1989. Foraging behavior of the predaceous cladoceran, Leptodora kindti, and escape responses of their prey. J. Plankton Res. 11: 1075-1088.

Chow-Fraser, P., AND C. K. Wong. 1986. Dietary change during development in the freshwater calanoid copepod Epischura lacustris Forbes. Can. J. Fish. Aquat. Sci. 43: 938-944.

Cummins, K. W., AND OTHERs. 1969. Ecological energetics of a natural population of the predaceous zooplankter Leptodora kindtii Focke (Cladocera). Oikos 20: 189-223.

De Bernardi, R. 1974. The dynamics of a population of Daphnia hyalina Leydig in Lago Maggiore, northern Italy. Mem. Ist. Ital. Idrobiol. 31: 221243.

DoDson, S. I. 1974. Zooplankton competition and predation: An experimental test of the size-efficiency hypothesis. Ecology 55: 605-613.

Dorazio, R. M., J. A. Bowers, AND J. T. Lehman. 1987. Food-web manipulations influence grazer control of phytoplankton growth rates in Lake Michigan. J. Plankton Res. 9: 891-899.

EDMondson, S. T., AND A. H. LiTT. 1987. Conochilus in Lake Washington. Hydrobiologia 147: 157-162.

FrYer, G. 1957. The food of some freshwater cyclopoid copepods and its ecological significance. $\mathrm{J}$. Anim. Ecol. 26: 263-286.

Goulden, C. E., L. L. HenRy, AND A. J. Tessier. 1982. Body size, energy reserves, and competitive ability in three species of Cladocera. Ecology 63: 17801789.

HALl, D. J. 1964. An experimental approach to the dynamics of a natural population of Daphnia galeata mendotae. Ecology 45: 94-112.

HANeY, J. F., AND D. J. HAll. 1973. Sugar-coated Daphnia: A preservation technique for Cladocera. Limnol. Oceanogr. 18: 331-333.

KERFOOT, W. C. 1974. Egg-size cycle of a cladoceran. Ecology 55: 1259-1270.

2. 1977. Implications of copepod predation. Limnol. Oceanogr. 22: 316-325.

- 1980. Perspectives on cyclomorphosis: Separation of phenotypes and genotypes. Am. Soc. Limnol. Oceanogr. Spec. Symp. 3: 470-496. New England.

LehMAN, J. T. 1987. Palearctic predator invades North American Great Lakes. Oecologia 74: 478-480.

— 1988. Algal biomass unaltered by food-web changes in Lake Michigan. Nature 322: 537-538.

, J. A. Bowers, R. W. GENSEMER, G. J. WARREN, AND D. K. BRANSTRATOR. 1990. Mysis relicta in Lake Michigan: Abundances and relationships with their potential prey, Daphnia. Can. J. Fish. Aquat. Sci. 47: 977-983.

LYNCH, M. 1980. The evolution of cladoceran life histories. Q. Rev. Biol. 55: 23-42. 
Mordukhai-Boltovskaia, E. D. 1958. Preliminary notes on the feeding of the carnivorous cladocerans Leptodora kindtii and Bythotrephes. Dokl. Akad. Nauk SSSR Biol. Sci. Sect. 122: 828-830.

Nero, R. W., AND W. G. Sprules. 1986. Predation by three glacial opportunists on natural zooplankton communities. Can. J. Zool. 64: 57-64.

Paloheimo, J. E. 1974. Calculation of instantaneous birth rate. Limnol. Oceanogr. 19: 692-694.

Prophet, C. W. 1982. Zooplankton changes in a Kansas lake 1963-1981. J. Freshwater Ecol. 1: 569_ 575.

SANDGRen, C. D., AND J. T. Lehman. 1990. Response of chlorophyll- $a$, phytoplankton, and microzooplankton to the invasion of Lake Michigan by $B y$ thotrephes. Int. Ver. Theor. Angew. Limnol. Verh. 24: 386-392.
VIJVERBERG, J. 1980. Effect of temperature in laboratory studies on development and growth of Cladocera and Copepoda from Tjeukemeer, The Netherlands. Freshwater Biol. 10: 317-340.

WARren, G. J., and J. T. LehMaN. 1988. Young-ofthe-year Coregonus hoyi in Lake Michigan: Prey selection and influence on the zooplankton community. J. Great Lakes Res. 14: 420-426.

WeLls, L. 1970. Effects of alcwife predation on zooplankton populations in Lake Michigan. Limnol. Oceanogr. 15: 556-565.

WrIGHT, D. J. 1965. The population dynamics and production of Daphnia in Canyon Ferry Reservoir, Montana. Limnol. Oceanogr. 10: 583-590.

Submitted: 3 August 1989 Accepted: 3 December 1990 Revised: 18 January 1991 